\title{
Privatisasi: Kinerja Keuangan dan Distribusi Laba \\ (Analisis Kritis Pada Pt Garuda Indonesia (Persero) Tbk)
}

\author{
Aviani Widyastuti, Gugus Irianto, M. Achsin \\ Universitas Brawijaya Malang \\ Surel: avianiw@gmail.com
}

\begin{abstract}
This study aims to analyze the privatization policy of PT Garuda Indonesia (Persero) Tbk. The critical paradigm using the Political Economy of Accounting (PEA) theoretical framework becomes a tool used to describe pre-privatization and post-privatization performance. The results showed that post-privatization Garuda Indonesia's financial performance tended to decrease. While the distribution of profits (wealth) to employees and shareholders (investors and government) is not done with the maximum. Distribution is only visible to employees and creditors but the increase is not due to the value distributed but it's because of the increase in the number of employees and the main requirement of Garuda Indonesia related to business expansion.
\end{abstract}

\section{PENDAHULUAN}

Perbaikan sektor perekonomian di Indonesia, khususnya pada Badan Usaha Milik Negara (BUMN) seringkali dikaitkan dengan kebijakan privatisasi. Privatisasi masih menjadi alternative pilihan yang berarti bagi pemerintah sebagai upaya "penyehatan" BUMN di Indonesia. Rangkaian kebijakan tersebut dimulai dari restrukturisasi baik dari keuangan dan manajemen, kemudian dilanjutkan dengan profitisasi dan privatisasi. Restrukturisasi erat kaitannya dengan tatanan makro dalam hal kebijakan politik, sementara profitisasi terkait upaya dalam peningkatan laba sebagai langkah lanjut dalam proses restrukturisasi. Sedangkan privatisasi sendiri merupakan upaya pemerintah dalam mengurangi peran Negara yang berlebih di sektor bisnis, dalam rangka menggerakkan dan memberdayakan perekonomian masyarakat (Widjajanti, 2013).

Tahun 1990-1998 penjualan saham BUMN tampak berhasil dengan mengundang para investor asing, swasta dan domestik untuk berpartisipasi dalam memiliki saham BUMN. Partisipasi ini tampaknya mampu memberikan penjualan dan menciptakan pendapatan US\$4,34 Miliar, dimana 55\% masuk ke dalam kas Negara dan sisanya dikembalikan ke BUMN yang bersangkutan (Marita, 2011). Akan tetapi, masalah mulai bermunculan dikala penjualan aset dan kerjasama dengan swasta mulai mengemban misi korupsi dan manipulasi. Beberapa aset BUMN dilepas dan diobral kepada swasta yang sangat dekat dengan keluarga dan kroni penguasa. Sebut saja, tanah dan bangunan PT Wisma Nusantara bernilai tinggi yang ada di Jakarta Pusat, justru diobral kepada Bimantara untuk dibangun hotel dan pusat pertokoan mewah. Hal serupa juga terjadi pada jaringan pemancar kebanggaan Indonesia dahulu kala yaitu TVRI disewakan dengan harga super murah kepada TPI. Bentuk restrukturisasi BUMN seperti ini lebih menyerupai atau lebih pantas disebut sebagai penjarahan pada BUMN.

BUMN yang mengemban tugas selain sebagai agen Negara dalam memastikan kesejahteraan rakyat, juga mengemban misi sebagai entitas bisnis untuk dapat mengejar keuntungan sebesar-besarnya. Akan tetapi, dalam prakteknya BUMN tidak mudah dalam menjaga keseimbangan antara amanat institusi dan sekaligus sebagai entitas bisnis yang berorientasi pada keuntungan. Meskipun pemerintah sudah melakukan berbagai upaya dalam menyelamatkan tugas BUMN

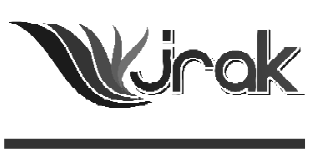

Jurnal Reviu Akuntansi dan Keuangan ISSN: 2088-0685 Vol.5 No. 1, April 2015 Pp 695-704 
Privatisasi: Kinerja

Keuangan...

696 dari berbagai macam permasalahan yang ada agar tercapai cita-cita bersama sesuai dengan cita-cita kemerdekaan. BUMN harus tetap diselamatkan dan dikelola dengan baik sesuai dengan tujuan peningkatan kesejahteraan. Dalam hal ini pemerintah masih menganggap bahwa privatisasi sebagai upaya menyelamatkan keuangan perusahaan Negara agar tidak membebani anggaran Negara. Meskipun pada kenyataannya dengan menyerahkan perusahaan Negara pada mekanisme pasar tidak sepenuhnya mampu menyelesaikan permasalahaan yang ada.

Josiah, Burton, Gallhofer, \& Haslam (2010) melakukan penelitian atas privatisasi yang terjadi di Afrika. Keterkaitan privatisasi dan akuntansi merupakan fokus yang luas. Penilaian privatisasi telah dipertimbangkan dalam lingkup gerakan audit sosial. Privatisasi yang terjadi di Afrika kontroversial. Dalam konteks ini sering menjadi bagian integral dari bentuk tertentu dari proses globalisasi dan membawa ambiguitas terkait. Tampaknya privatisasi merupakan suatu obat mujarab bagi para pendukungnya. Penelitian tersebut mencakup perhatian terhadap mobilisasi dalam konteks berbagai laporan serta praktik tata kelola pemerintahan terkait di tingkat mikro dan makro. Di mana, pada gilirannya mencerminkan pengertian akuntansi bersama dengan sistem tata kelola terkait dan meresap dalam proses privatisasi. Hasil penelitian menunjukkan adanya kekurangan dan kesenjangan dari teori kritis dan perspektif interdisipliner. Kesenjangan dan kekurangan ini membatasi wacana kebijakan dan praksis Vis-à-vis privatisasi di Afrika dan sekitarnya. Mereka juga menunjuk pada akuntansi yang lebih holistik dan mengetahui kekhasan Afrika, dan memang berbeda dengan Negara lain.

Irianto (2004), lebih jelas mengungkapkan dalam penelitiannya pada PT Semen Gresik Tbk. Privatisasi perusahaan ini dilakukan sebagai bagian dari reformasi kebijakan yang lebih luas dan dilaksanakan di tiga kali berturut-turut pada tahun 1991, 1995, dan 1998. Divestasi bertahap tersebut selesai dalam konteks yang berbeda. Sementara Pemerintah dalam hal ini juga gagal dalam mengatasi masalah mendasar dari distribusi kekayaan dan kekuasaan setelah privatisasi.

Penelitian serupa juga dilakukan oleh Sokarina (2011), yang mengungkapkan dalam hasil penelitiannya pada kinerja PT Telkomsel, dimana privatisasi telah gagal dalam mendistribusikan kepemilikan. Hal ini ditandai adanya proses eksploitasi terhadap konsumen melalui bentuk tarif yang cukup tinggi. Sehingga, dalam mengukur kinerja khususya BUMN tidak hanya cukup dengan mempertimbangkan kinerja keuangan dan kinerja lingkungan semata, tetapi juga dengan mempertimbangkan adanya kesadaran sosial dan juga kesadaran politik.

Shaoul (1997a) lebih lanjut juga melakukan penelitian dengan menggunakan PEA untuk menguji kasus privatisasi pada perusahaan air minum di Inggris. Pada penelitian pertama, Shaoul menguji klaim pemerintah bahwa privatisasi semakin meningkatkan efisiensi bagi industri, pelanggan, dan Negara. Hasil penelitiannya menunjukkan ternyata tidak terjadi peningkatan efisiensi dan distribusi laba dan dipandang sebagai konflik antara publik dengan pemegang saham. Sedangkan pada penelitian kedua, Shaoul (1997b) melakukan pengujian pada model akuntansi dan akun keuangan pada laporan tahunan serta menguji constructive dan emancipatory dari peran akuntansi dalam menghadapi berbagai masalah publik. Hasilnya menujukkan bahwa model akuntansi yang tersedia untuk publik dapat digunakan sebagai data untuk menganalisis tujuan sosial dan kritik ekonomi. Selain itu, akuntansi dapat berperan sebagai pembangun (constructive) dan pembebas (emancipatory) bagi berbagai masalah yang timbul.

Terkait dengan penilaian kinerja BUMN, berbagai indikator menjadi suatu pertimbangan. Terutama dalam aspek keuangan, indikator profitabilitas menjadi komponen penting dalam mengukur keberhasilan kinerja BUMN pasca privatisasi. Akan tetapi di sisi lain, lebih lanjut bila melihat konsep Political Economy Of Accounting (PEA) yang dipelopori oleh Tinker (1980) bahwa keadilan sosial yang dimaksud adalah keadilan yang mampu mensejahterakan tidak hanya kepada shareholder tetapi lebih dari itu juga kepada stakeholder. Dan pemerintah sebagai pihak agen dalam teori agency dipercaya oleh pihak principal (rakyat) dalam 
mengelola kekayaan yang menguasai hajat hidup orang banyak sesuai dengan amanat dalam UUD 1945. Sehingga, kebijakan privatisasi yang diambil oleh pemerintah dalam upaya peningkatan kinerja BUMN ini pun tentunya tak terlepas dari adanya kebermanfaatan bersama yang mampu dirasakan oleh sebagian besar orang.

Kinerja Garuda Indonesia, sebagai salah satu BUMN di Indonesia yang bergerak dalam industri penerbangan, juga menjadi sorotan yang cukup menarik. Mengingat Industri jasa penerbangan, khususnya penerbangan komersial kian ramai di Indonesia. Perkembangan jasa pelayanan maskapai penerbangan dari tahun ke tahun juga menjadi salah satu perhatian masyarakat luas. Semakin tingginya persaingan pelayanan, harga dan promosi yang ditawarkan menjadi salah satu hal yang membuktikan betapa industri jasa penerbangan ini sangat diminati belakangan ini. Potensi bisnis industri jasa penerbangan di Indonesia juga sangat besar mengingat kondisi geografis Indonesia yang terdiri dari kepulauan. Transportasi udara merupakan salah satu pilihan utama yang sangat praktis untuk dapat menjangkau antara pulau yang satu dengan lainnya. Untuk menjadi perusahaan yang kompetitif tentunya perlu memenuhi sejumlah kriteria misalnya kepuasan pelanggan yang bersifat dinamis dan juga kemajuan teknologi telekomunikasi dan teknologi informasi.

Garuda Indonesia merupakan perusahaan penerbangan di Indonesia yang cukup "Fight". Dari awal berdiri sampai mencapai keberhasilan, Garuda sempat mengalami goncangan finansial saat krisis moneter dan akhirnya dilakukan privatisasi sebagai upaya kebangkitannya dari keterpurukan. Pada kenyataannya, privatisasi pada Garuda Indonesia saat ini memang membawa keberhasilan yang cukup siginifikan dengan ditandai mampunya bersaing di dunia penerbangan internasional. Bahkan Garuda Indonesia juga telah menjadi sponsorship pada salah satu club sepak bola internasional. Melihat Garuda Indonesia yang masih merupakan perusahaan negara, beberapa hal juga menjadi perlu diperhatikan. Garuda Indonesia dalam hal ini masih mengemban tugas selain sebagai entitas bisnis yang wajib mendistribusikan deviden pada APBN, juga mengemban tugas sebagai agen negara yang memastikan terjadi hak kesejahteraan pada setiap penduduk Indonesia. Sedangkan melihat kenyataan bahwa pada umumnya, pengguna layanan penerbangan ini adalah masyarakat ekonomi menengah ke atas. Meskipun hal ini menunjukkan adanya kemampuan Garuda Indonesia Indonesia untuk bersaing seperti yang menjadi tujuan dari privatisasi, akan tetapi juga menjadi sebuah pertanyaan, sejauh mana masyarakat Indonesia mampu menikmati keberhasilan atas privatisasi yang dilakukan pada Garuda Indonesia itu sendiri, melihat jasa penerbangan tersebut merupakan BUMN yang juga mengemban amanat bagi kesejahteraan masyarakat Indonesia pada umumnya.

\section{METODE PENELITIAN}

Penelitian ini merupakan penelitian kualitatif dengan menggunakan paradigma kritis. Patti Lather dalam (Muhadjir, 2002) menjelaskan bahwa paradigma kritis termasuk pendekatan era postpositif, yang mencari makna di balik yang empiri dan menolak value free. Pendekatan teori kritis mempunyai komitmen yang tinggi kepada tata sosial yang lebih adil.

Pengumpulan data dalam penelitian ini menggunakan teknik dokumentasi. Sedangkan jenis data yang digunakan dalam penelitian ini adalah jenis data sekunder yang dapat diperoleh dengan mengakses situs online atau penelusuran secara online yaitu Pojok BEI yang ada di Universitas Muhamadiyah Malang, website Garuda, dan juga website media berita. Adapun laporan tahunan yang digunakan adalah tahun 2008-2014, di mana dibagi menjadi tiga periodisasi yaitu praprivatisasi (2008-2010), privatisasi (2011), dan pascaprivatisasi (2012-2014). 


\section{Privatisasi: Kinerja \\ Keuangan...}

Penelitian ini menggunakan model teorisasi dimana penelitian tidak perlu buta sama sekali terhadap teori, namun pemahamannya terhadap teori sebelumnya cukup membantu peneliti untuk memahami data yang akan diteliti atau dengan kata lain teori dalam hal ini sedikit banyak membantu peneliti membuka misteri data yang sebenarnya tidak diketahui oleh peneliti. Kerangka teori yang digunakan adalah Political Economy of Accounting (PEA) yang dipelopori oleh Tinker (1980). PEA yang selama ini cukup dikenal dan diintrodusir oleh Tinker (1980), merupakan salah satu rerangka teori yang berada pada ranah studi akuntansi kritis. Studi akuntansi kritis sendiri senantiasa dilakukan dalam konteks-konteks tertentu. Dimana, akuntansi bukan hanya dipandang sebagai suatu disiplin dalam ruang yang kosong, namun, akuntansi berada dalam konteks organisasi dan masyarakat tertentu. PEA dalam penelitian ini akan digunakan sebagai bagian dari alat untuk menilai kinerja kebijakan privatisasi pada Garuda Indonesia dengan melihat distribution of income, dimana dengan menawarkan tranformasi pandangan bahwa laba the bottom line menuju pandangan "a just and fair distribution". Tinker menyampaikan bahwa dalam pandangan ini didasarkan pada keyakinan bahwa laba merupakan indikator dari kelangsungan hidup dari suatu perusahaan dan juga sebagai alat yang dapat digunakan untuk mengukur efisiensi sosial dalam memanfaatkan sumber daya masyarkat, dan juga bukan hanya sekedar ukuran teknis efisiensi dalam konversi input ke output.

\section{HASIL DAN PEMBAHASAN}

\section{Rasio Keuangan}

Privatisasi yang dilakukan pemerintah pada Garuda Indonesia adalah untuk mendobrak keberhasilan yang lebih maju lagi. Garuda Indonesia membutuhkan modal yang cukup besar untuk bisa melakukan ekspansinya. Oleh karena itu, dengan menjual beberapa saham Garuda Indonesia kepada swasta maka diperlukan investor baru. Ditambah lagi, pemerintah merasa yakin bahwa privatisasi ini akan membawa keberhasilan. Hal ini disebabkan industri penerbangan di Indonesia yang cukup menjanjikan dikarenakan kondisi geografis Indonesia yang berupa kepulauan. Transportasi udara merupakan pilihan yang tepat dan lebih cepat yang dapat digunakan untuk melintasi antar pulau. Sehingga pemerintah pun yakin dengan dijualnya Garuda Indonesia justru membuat daya tarik tersendiri bagi investor yang akan menanamkan sahamnya.

Privatisasi di Indonesia bahkan memiliki payung hukum yang jelas. Undangundang Nomor 19 Tahun 2003 tentang Badan Usaha Milik Negara bahkan sudah mengatur terkait tujuan dan tata cara dilakukannya privatisasi terhadap BUMN. Selanjutnya secara teknis pengaturan dan pelaksanaan Privatisasi BUMN diatur oleh PP No.33 Tahun 2005 tentang Tata cara Privatisasi Perusahaan Perseroan (Persero) jo. PP No. 59 Tahun 2009 tetang Perubahan atas Peraturan Pemerintah No.33 Tahun 2005. Pasal-pasal yang diatur dalam peraturan tersebut hanya terkait dengan mekanisme privatisasi mengenai sektor permodalan saja. Sedangkan terkait manajemen bagi persero yang dikelola oleh swasta tidak diatur dalam peraturan tersebut.

Privatisasi pada Garuda Indonesia sendiri melalui proses yang cukup matang. Garuda Indonesia dari awal memang telah dipersiapkan untuk diprivatisasi mengingat peluang industri penerbangan yang cukup berarti. Meskipun Garuda Indonesia sempat mengalami krisis keuangan dan akhirnya melalui tangan Dirut Garuda Indonesia saat itu yaitu Emirsyah Satar, Garuda Indonesia akhirnya bangkit setelah melalui beberapa tahapan proses perbaikan hingga akhirnya membawa Garuda Indonesia pada tahap ekpansi. Tahap ekspansi inilah yang dijadikan alasan oleh pemerintah untuk melakukan privatisasi pada Garuda Indonesia Dengan kebutuhan modal yang tidak sedikit, maka pemerintah berani mengambil keputusan untuk melakukan privatisasi pada Garuda Indonesia dengan menawarkan sahamnya melalui IPO pada Bursa Saham. 
Garuda Indonesia menjalani proses privatisasi melalui proses restrukturisasi terlebih dahulu, dikarenakan kala itu kondisi keuangan Garuda sedang mengalami krisis. Akan tetapi restrukturisasi tersebut memang dilakukan sebagai persiapan Garuda Indonesia untuk menjalani privatisasi. Pemerintah selalu beranggapan bahwa dengan diprivatisasi maka kinerja perusahaan, khususnya kinerja keuangan perusahaan akan menjadi lebih baik.

Kinerja keuangan perusahaan seringkali merupakan hasil dari perusahaan pada periode tertentu yang didasarkan pada standar. Laporan Keuangan, dalam kaitannya dengan penilaian kinerja sudah menjadi sesuatu yang lazim untuk dijadikan dasar penilaian kinerja karena dianggap mampu mengukur keberhasilan operasi perusahaan dalam periode tertentu (Ujianto, 2007). Penilaian kinerja perusahaan pada umumnya menggunakan metode penilaian dengan ukuran keuangan dan non keuangan. Di mana, laba menjadi bagian ukuran utama yang sering digunakan dan menjadi potensial karena adanya pembanding berupa laporan keuangan di masa lalu atau yang sejenisnya (Hansen \& Mowen, 1997).

Laba selama ini memang dipandang sebagai bottom line dari laporan laba rugi yang tidak dapat dipisahkan dari ideologi politik yang menyadari konsep dan praktik akuntansi modern selama ini. Meskipun dengan menjadikan laba sebagai orientasi utama bisnis, pada kenyataannya membawa beberapa implikasi yang sedemikian rupa. Sama halnya fenomena-fenomena dari kasus yang relatif kecil hingga kelas kakap yang disampaikan oleh Irianto (2006), bahwa penggunaan formalin, borak dan zat-zat kimia yang berbahaya lainnya juga dilatar belakangi upaya mengejar laba. Tuntutan ekonomi (menghasilkan laba) akhirnya menjadi suatu dorongan kuat atau tekanan tertentu untuk melakukan segala cara agar dapat mencapainya.

Rasio-rasio keuangan yang ditampilkan dari laporan perusahaan selama ini menunjukkan pertumbuhan kinerja pada perusahaan. Melalui beberapa rasio keuangan yang ada, maka pertumbuhan kinerja pada Garuda Indonesia pun dapat tergambarkan. Seperti pada uraian berikut akan digambarkan pertumbuhan kinerja Garuda Indonesia melalui ukuran rasio: (1) Rasio laba usaha terhadap pendapatan usaha; (2) Laba usaha terhadap jumlah ekuitas; (3) Laba usaha terhadap aset; (4) Margin EBITDA; (5) Margin laba bersih; (6) Pengembalian modal; (7) Pengembalian aset (8) Rasio lancar; (9) Rasio hutang terhadap ekuitas; (10) Rasio total kewajiban terhadap total aktiva; (11) Price earning Ratio (PER). Rasiorasio tersebut akan digambarkan dengan melalui periodisasi pra privatisasi, privatiasasi dan pasca privatisasi.

\begin{tabular}{|c|c|c|c|c|c|c|c|}
\hline \multirow[t]{2}{*}{ Rasio } & \multicolumn{3}{|c|}{ Pasca Privatisasi } & \multirow{2}{*}{$\frac{\text { Privatisasi }}{2011}$} & \multicolumn{3}{|c|}{ Praprivatisasi } \\
\hline & 2014 & 2013 & 2012 & & 2010 & 2009 & 2008 \\
\hline $\begin{array}{l}\text { Rasio laba usaha } \\
\text { terhadap } \\
\text { pendapatan usaha }\end{array}$ & -10.15 & 1.52 & 4.84 & 3.72 & -0.3 & 5.14 & 6.12 \\
\hline $\begin{array}{l}\text { Laba usaha } \\
\text { terhadap jumlah } \\
\text { ekuitas }\end{array}$ & -43.56 & 5.05 & 15.07 & 13.41 & -1.9 & 28.57 & 466.13 \\
\hline $\begin{array}{l}\text { Laba usaha } \\
\text { terhadap aset }\end{array}$ & -12.88 & 1.91 & 6.67 & 5.62 & -0.5 & 6.20 & 9.08 \\
\hline Margin EBITDA & -5.60 & 5.86 & 8.58 & 7.19 & 7.44 & 13.41 & 7.7 \\
\hline Margin laba bersih & -9.50 & 0.30 & 3.19 & 2.61 & 2.8 & 6.10 & 3.7 \\
\hline $\begin{array}{l}\text { Pengembalian } \\
\text { modal }\end{array}$ & -40.6 & 1.00 & 9.94 & 10.88 & 14.91 & 39.08 & 165.7 \\
\hline Pengembalian aset & -12 & 0.38 & 4.40 & 4.17 & 3.87 & 7.38 & 5.3 \\
\hline Rasio lancar & 0.67 & 0.83 & 0.84 & 0.94 & 0.56 & 0.55 & 0.6 \\
\hline $\begin{array}{l}\text { Rasio hutang } \\
\text { terhadap ekuitas }\end{array}$ & 238.30 & 164.4 & 125.84 & 125,73 & 286 & 347 & 982 \\
\hline $\begin{array}{l}\text { Rasio total utang } \\
\text { terhadap total aset }\end{array}$ & 70.40 & 62.18 & 55.72 & 58 & 75 & 78 & 98 \\
\hline $\begin{array}{l}\text { Price earning Ratio } \\
\text { (PER) }\end{array}$ & $(30,764.08)$ & $936,734.69$ & $93,673.47$ & 13.74 & $35,383.56$ & 8.95 & 12.18 \\
\hline
\end{tabular}

Tabel 1

Pertumbuhan

Kinerja PT Garuda Indonesia Airlines

Tahun 2008-2014

(dalam persen) 


\section{Privatisasi: Kinerja \\ Keuangan...}

700
Berdasarkan tabel 1 di atas maka dapat dilihat pertumbuhan kinerja keuangan pada PT Garuda Indonesia dari tahun 2008 hingga tahun 2014. Bila melihat secara periodisasi, maka dapat dilihat berdasarkan 3 (tiga) periodisasi yaitu sebelum privatisasi (praprivatisasi), masa privatisasi dan setelah dilakukan privatisasi (Pasca Privatisasi). Bila dilihat dari tahun ke tahun rasio perbandingan laba terhadap pendapatan usaha mengalami penurunan terus-menerus. Penurunan tajam ini terutama terjadi pada tahun 2010 pada saat persiapan untuk dilakukannya privatisasi yaitu dari 5,14\% hingga menjadi -0,3. Penurunan tajam terjadi kembali pada tahun 2013 dan 2014 yang bahkan mencapai -10.15\%. Penurunan yang terjadi pada tahun 2010 ini disebabkan karena Garuda Indonesia melakukan penyelesaian restrukturisasi hutangnya sebesar $\$ 277$ juta, sebagai persiapan penting untuk melakukan Penawaran Umun Perdana Saham dalam rangka ekspansi usaha di masa mendatang. Pada tahun 2013 perkonomian Indonesia meghadapi banyak tantangan, di mana anggaran pemerintah membuat pemerintah menaikkan harga BBM bersubsidi yang memicu tingginya inflasi domestik pada tahun tersebut sehingga rasio laba terhadap pendapatan usaha pada tahun 2013 juga mengalami penurunan. Sedangkan penurunan yang terjadi pada tahun 2014 disebabkan karena pada 10 Desember 2014, Perseroan melakukan transaksi akuisisi atas saham GA yang dimiliki oleh PT Angkasa Pura I. Dan bila dilihat secara keselurusan berdasarkan periodisasinya rasio ini terus mengalami kenaikan meskipun tidak terlalu signifikan dari sebelum privatiasi hingga dilakukan privatisasi yaitu pada pravitasi rata-rata $3,65 \%$ dan pada masa privatisasi $3,72 \%$. Sedangkan pada pasca privatisasi justru mengalami penurunan yaitu rata-rata $3,79 \%$.

Rasio laba usaha terhadap ekuitas Garuda Indonesia pada tiga masa periodisasi membukukan rata-rata pada praprivatisasi $164,26 \%$, pada masa privatisasi $13,41 \%$ dan pasca privatisasi rata-rata $-7,81 \%$. Hal ini menunjukkan bahwa rasio ini terus mengalami penurunan terutama pada pasca privatisasi. Pecapaian tertinggi terjadi pada tahun 2008 yang merupakan awal tahun tranformasi Garuda Indonesia dengan langkah restrukturisasi keuangan sehingga meningkatnya laba yang cukup signifikan dari tahun 2007 ke tahun 2008.

Garuda Indonesia juga mencatat laba usahanya terhadap aset mengalami kenaikan pada masa privatisasi yaitu dari $4,92 \%$ pada pra privatisasi menjadi $5,62 \%$. Sayangnya, kondisi ini tidak mampu dipertahankan pada pasca privatisasi karena mengalami penurunan yaitu rata-rata $-1,43 \%$. Hal ini terutama terlihat tajam terjadi pada tahun $2014(-12,88 \%)$.

EBITDA juga merupakan salah satu penilaian yang digunakan dalam mengukur kinerja keuangan dengan melihat laba sebelum bunga, penghasilan dan beban non usaha lainnya. Dari margin EBITDA yang digambarkan dalam laporan keuangan Garuda Indonesia menunjukkan pada masa privatisasi sempat mengalami penurunan dari masa praprivatisasi yaitu dari rata-rata $9,52 \%$ menjadi $7,19 \%$, dan kembali mengalami penurunan drastis pada masa pasca privatisasi yaitu menjadi rata-rata $2,95 \%$.

Sayangnya, Garuda Indonesia tidak mampu mempertahankan kinerja margin laba bersihnya. Dari pra privatisasi hingga pasca privatisasi mengalami penurunan terus-menerus yaitu dari rata-rata 4,2\%, 2,61\% dan hingga - $2 \%$ pada pasca privatisasi. Bisa dikatakan pasca privatisasi perusahaan tidak menunjukkan kinerja yang baik.

Pengambalian modal dan asset pada Garuda Indonesia juga membukukan penurunan terus menerus dari masa pra privatisasi hingga pasca privatisasi. Pengembalian modal mencatat rata-rata pada masa pra privatisasi sebesar $73,23 \%$, masa privatisasi $10,88 \%$ sedangkan pasca privatisasi $-9.88 \%$. Sama halnya pada pengembalian aset yang terjadi terus mengalami penurunan yaitu rata-rata $5.52 \%$ pada masa pra privatisasi, $4,17 \%$ pada privatisasi dan turun lagi pada masa pasca privatisasi menjadi $-2,41 \%$. Hal ini menunjukkan bahwa tingkat pengembalian modal pada pemegang saham lebih buruk dibandingkan pada masa pra privatisasi 
dan manajemen Garuda Indonesia kurang efektif dalam memanfaatkan sumberdaya dimiliki pada masa pasca privatisasi.

Pascaprivatisasi, Garuda Indonesia menunjukkan bahwa belum mampu mengelola likuiditasnya lebih optimal. Pembukuan Garuda Indonesia telah membukukan rata-rata 0,57 kali pada pra privatisasi, 0.94 kali pada masa privatisasi dan mengalami penurunan 0,78 kali pada pasca privatisasi. Sedangkan bila melihat dari rasio utang terhadap ekuitas yang merupakan pendanaan operasi perusahaan didanai oleh utang. Garuda Indonesia mencatat prosentase rasio utang terhadap ekuitas semakin rendah atau tingkat solvabilitas yang semakin tinggi dari masa pra privatisasi hingga diprivatisasi yang artinya resiko perusahaan semakin rendah yaitu dari tahun 2008 hingga 2011 masing-masing mencatat 982\%, 347\%, 286\% dan $125,73 \%$. Sayangnya pada masa pasca privatisasi tingkat solvabilitas Garuda Indonesia semakin turun yang artinya resiko perusahaan juga semakin tinggi yaitu tahun 2012 hingga 2014 masing-masing mencatat 125,84\%, 164,4\% dan $238,3 \%$.

Rasio total utang terhadap total aktiva atau rasio utang adalah mengukur persentase total dana yang disediakan para kreditor. Dalam hal ini, Garuda Indonesia sempat mengalami penurunan pada masa pra privatisasi yaitu pada tahun 2008 hingga tahun 2010 yaitu 98\%, 78\%, dan 75\%. Saat diprivatisasi rasio ini kembali mengalami penurunan yaitu $58 \%$ tetapi pada pasca privatisasi kembali mengalami kenaikan dari tahun 2012 hingga 2014 yaitu 55,72\%, 62,18\% dan $70,40 \%$. Rasio total utang terhadap aktiva yang semakin tinggi menurut pemilik perusahaan merupakan suatu kondisi yang mengutungkan karena utang yang tinggi akan memperbesar laba bagi pemegang saham atau menerbitkan saham baru berarti melepaskan sejumlah kendali perusahaan (Ross, 2015).

PT Garuda Indonesia mencatat nilai PER yang sangat berflutuasi, meskipun pada masa pascaprivatisasi menunjukkan kecenderungan naik pada tahun 2012 dan tahun 2013 yaitu 93.673,47 kali dan 936.734,69 kali pada tahun 2014 yang mengalami penurunan yang drastis yaitu -30.764,08). Sehingga bila melihat secara rata-rata nilai PER pada pascaprivatisasi justru mengalami penurunan dibanding nilai rata-rata pada praprivatisasi yaitu $11.801,56$ kali yang artinya harga saham pada praprivatisasi merupakan kelipatan $11.801,56$ kali earnings perusahaan.

\section{Distribusi Laba melalui Analisis Laporan Nilai Tambah}

Choi \& Mueller (1992) dalam Samudro (2004) mengungkapkan bahwa laporan nilai tambah merupakan modifikasi dari laporan laba rugi yang juga dapat diartikan sebagai pertambahan kekayaan yang dihasilkan dari penggunaan produktif sumber daya perusahaan yang dialokasikan kepada pemegang saham, pemegang obligasi, kreditor, pekerja, dan pemerintah. Definisi lain juga menyatakan bahwa nilai tambah merupakan beda antara nilai output perusahaan dengan nilai input perusahaan.

Laporan nilai tambah merupakan laporan yang menjadi sangat popular di Inggris bahkan menjadi laporan mandatory di Inggris sehingga semua perusahaan di Inggris memiliki laporan nilai tambah (Sokarina, 2011a). Laporan ini menjadi polular setelah adanya publikasi Corporate Report oleh Accounting Standards Streering Committee pada Agustus tahun 1975. Meskipun, laporan ini penggunaanya belum meluas layaknya laporan laba rugi konvensional. Dalam publikasi tersebut disampaikan pula terkait dengan alasan utama direkomendasikan laporan nilai tambah, diantaranya adalah sebagai cara yang mudah dan cepat dalam memposisikan keuantungan sebagai hasil usaha bersama pada sudut pandang yang benar yaitu antara modal, manajemen, dan para pekerja dalam suatu perushaan. Selain itu, laporan nilai tambah ini juga dapat digunakan sebagai alat untuk mengukur kinerja dan aktivitas keuangan suatu perusahaan dan juga sebagai alat prediksi yang andal untuk memprediksi dan mendeteksi keadaan ekonomi untuk kepentingan perusahaan. 


\section{Privatisasi: Kinerja \\ Keuangan...}

702
Laporan keuangan di Indonesia sendiri masih mengacu pada Pernyataan Standar Akuntansi Keuangan (PSAK) yang mana masih mengacu pada teori entitas. Teori entitas sendiri lebih mengutamakan pada sudut pandang untuk melindungi kepentingan pemilik modal. Sementara bila dibandingkan dengan laporan nilai tambah dapat mengukur kinerja perusahaan dengan melibatkan distribusi keuntungan yang tidak hanya mengutamakan kepada pemegang saham, tetapi juga pekerja, pemodal dan juga pemerintah.

Penelitian Sokarina (2011), menggunakan laporan nilai tambah sebagai kacamata yang dapat digunakan untuk menganaisis distribusi laba perusahaan kepada stakeholders. Karena dalam laporan nilai tambah menggambarkan kondisi pengalokasian nilai tambah diantara partner kerja perusahaan yang terdiri dari kelompok pekerja, kelompok pemegang saham, kelompok pemegang obligasi, kreditor dan pemerintah. Adapun beberapa rasio yang dapat digunakan dalam menganalisis (Morley, 1979) yaitu rasio nilai tambah terhadap upah, rasio pajak terhadap nilai tambah, rasio nilai tambah terhadap pendapatan usaha, dan rasio nilai tambah terhadap penyusutan. Rasio-rasio tersebut akan digunakan pula dalam penetian ini guna menganalisis distribusi laba dari PT Garuda Indonesia, utamanya adalah membandingkan nilai tambah perusahaan sebelum privatisasi dan sesudah privatisasi.

Berdasarkan laporan nilai tambah komparasi PT Garuda Indonesia pada tahun 2008 hingga 2014 menunjukkan bahwa rata-rata nilai tambah pada pascaprivatisasi mengalami kenaikan yaitu $\$ 408.531$ atau setara sekitar 4,9 triliun rupiah (lihat tabel 5.2). Rata-rata porsi nilai tambah pada PT Garuda Indonesia menunjukkan sebagian besar dialokasikan pada karyawan. Rata-rata alokasi nilai tambah terhadap karyawan pada masa praprivatisasi mencatat hingga $71 \%$ dan terus meningkat hingga pascaprivatisasi yang mencapai rata-rata $116 \%$.

Peningkatan biaya karyawan yang terjadi pada PT Garuda Indonesia dikarenakan adanya rata-rata kenaikan gaji karyawan tiap tahunnya dan juga diikuti jumlah karyawan yang naik. Terutama kenaikan jumlah karyawan tersebut terjadi lonjakan yang cukup besar di tahun 2014 yaitu 8.488 karyawan termasuk jumalah pegawai Garuda Airlines dan SBU GSM, SBU Garuda Cargo, SBU Citilink. Komponen-komponen beban karyawan yang dialokasikan ini termasuk di dalamnya adalah gaji, imbalan kerja jangka pendek, imbalan kerja pasca kerja, tunjangan, insentif dan pesangon pemutusan kontrak kerja.

Alokasi nilai tambah yang diberikan kepada pemegang saham atau dalam hal ini yang direpresentasikan dalam bentuk deviden sayangnya tidak tampak dari tahun 2008 hingga tahun 2014. Hal ini menunjukkan bahwa tidak adanya pembayaran deviden yang dilakukan oleh PT Garuda Indonesia dari tahun 2008 hingga tahun 2014. Sedangkan alokasi kepada kreditor atau dalam bentuk pembayaran bunga cenderung mengalami penurunan dari tahun 2008 hingga 2012 yaitu $11 \%, 6 \%, 6 \%, 4 \%, 5 \%$, yang kemudian mengalami kenaikan kembali pada tahun 2013 dan tahun 2014 yaitu 14\% dan 30\%.

Nilai tambah juga menjadi bagian yang didistribusikan kepada pemerintah atau dalam hal ini direpresentasikan dalam bentuk pajak yang dibayarkan oleh PT Garuda Indonesia. Dari tahun 2008 hingga tahun 2014 PT Garuda Indonesia mencatat pembayaran pajak yang sangat fluktuatif. Tahun 2008 PT Garuda Indonesia mencatat pembayaran pajaknya $3 \%$ dari nilai tambah atau sekitar 96,7 Millyar Rupiah. Sedangkan di tahun 2009 dan juga tahun 2010, pembayaran pajak PT Garuda Indonesia menunjukkan angka minus yaitu -23,3M dan -217,2 M. Hal ini menunjukkan bahwa pada tahun 2009 dan 2010 PT Garuda Indonesia memiliki manfaat pajak atau belum memnfaatkan kredit pajak pada tahun-tahun sebelumnya dan baru dimanfaatkan pada tahun 2009 dan 2010. Manfaat pajak ini pun kembali tercatat di tahun 2013 dan tahun 2014, sementara di tahun 2011 PT Garuda Indonesia harus mendistribusikan nilai tambahnya untuk pemerintah sebesar 193,9 M. 
Laba ditahan pada yang dicatat oleh PT Garuda Indonesia juga kecenderungan mengalami penurunan dari tahun 2008 hingga tahun 2010 atau masa praprivatisasi yaitu rata-rata $20 \%$ dari nilai tambah dan pada masa privatisasi mencatat $17 \%$ dari nilai tambah atau $817 \mathrm{M}$. Sedangkan pada masa pasca privatisasi nominal laba ditahan terus mengalami penurunan dari tahun 2012 hingga tahun 2014 yaitu 127Juta Dollar, 8,7 Juta Dollar dan minus ditahun 2014 yaitu 272,5 juta Dollar.

Nilai tambah yang terjadi pada Garuda Indonesia secara keseluruhan menunjukkan tren yang naik dari praprivatisasi hingga pascaprivatisasi kecuali pada tahun 2014 yang mengalami penurunan tajam. Namun sayangnya, nilai tambah tersebut tidak mampu didistribusikan secara merata dan stabil kepada para stakeholders. Nilai tambah yang distribusikan kepada karyawan saja yang tampak konsisten mengalami kenaikan terus menerus dari praprivatisasi hingga pascaprivatisasi, meskipun kenaikan tersebut karena adanya kenaikan jumlah karyawan. Sementara itu bila melihat distribusi nilai tambah kepada kreditor mengalami tren yang naik pada pascaprivatisasi. Sedangkan distribusi kepada stakeholders yang lain (pajak dan laba ditahan) menunjukkan tren yang cenderung menurun.

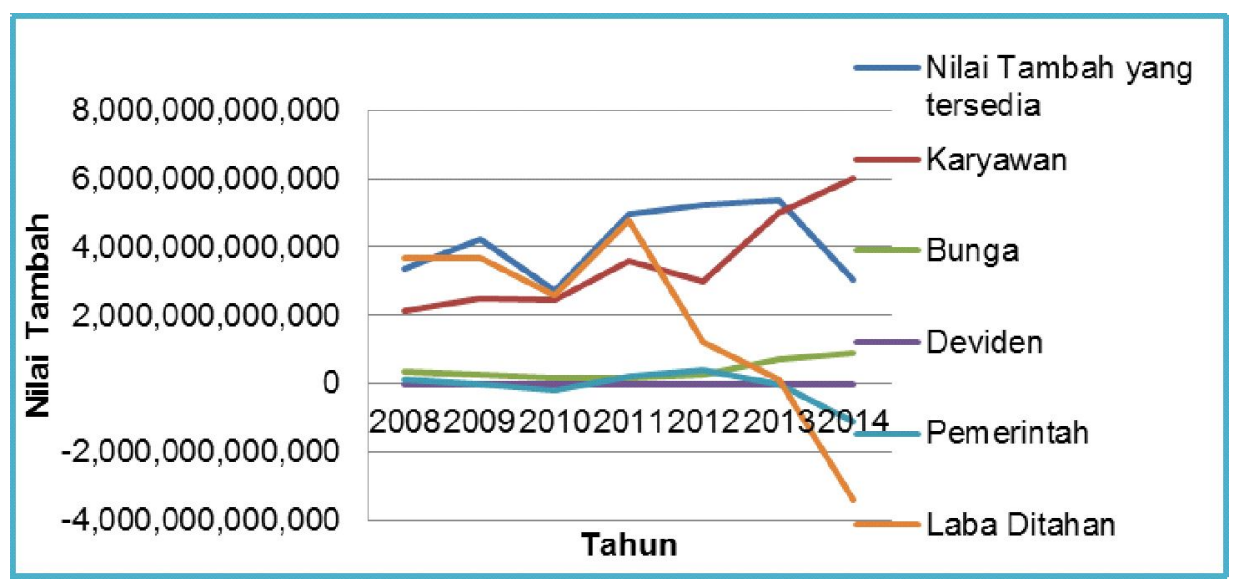

\section{KESIMPULAN}

Melalui kerangka teori PEA, dapat disimpulkan beberapa hasil temuan penelitian atas penilaian kinerja praprivatisasi dan pascaprivatisasi pada Garuda Indonesia, sebagai berikut:

a. Wacana yang terbangun dalam laporan keuangan perusahaan, privatisasi yang dilakukan pemerintah terhadap Garuda Indonesia nyatanya tidak memberikan gambaran kinerja yang bagus. Meskipun pemerintah selalu mengandalkan privatisasi sebagai upaya yang dapat ditempuh untuk meningkatkan kinerja BUMN. Hal ini ditunjukkan pada hasil perhitungan rasio-rasio kinerja keuangan yang pada tael 3.1. Pada pascaprivatsasi rata-rata kinerja keuangan Garuda Indonesia tidak menunjukkan hasil yang memuasakan.

b. Realitas sosial politik privatisasi yang dilakukan terhadap Garuda Indonesia gagal melakukan distribusi labanya. Wacana ini tergambar dalam nilai tambah Garuda Indonesia yang tidak dapat terdistribusikan secara maksimal kepada para partner kerjanya yaitu pemerintah, kreditor, karyawan, pemilik modal. Kenaikan nilai tambah yang diperoleh setelah privatisasi tidak diimbangi dengan pembagian distribusi yang maksimal. Meskipun distribusi kepada karyawan tampak meningkat, kenyataannya kenaikan tersebut bukan berasal dari nilai yang diberikan keapada karyawan tetapi karena adanya kenaikan jumlah karyawan. 


\section{Privatisasi: Kinerja \\ Keuangan...}

704

\section{DAFTAR PUSTAKA}

Annual Report PT Garuda Indonesia (Persero) Tbk. 2008-2014. diakses tanggal 30 Juli 2016 dari Pojok BEI UMM.

Hansen, \& Mowen. (1997). Akuntansi Manajerial. Salemba Empat.

Irianto G. (2004). A Critical Enquiry Into Privatisation of State-Owned Enterprises: The Case of PT Semen Gresik (Persero) TBK. Indonesia.

Irianto, G. (2006). Dilema "Laba" dan Rerangka Teori Political Economy of Accounting (PEA). TEMA, $7(2)$.

Josiah, J., Burton, B., Gallhofer, S., \& Haslam, J. (2010). Accounting for privatisation in Africa/ ? Reflections from A Critical Interdisciplinary Perspective. Critical Perspectives on Accounting, 21(5), 374-389. doi:10.1016/j.cpa.2009.09.002

Marita, D. (2011). Privatisasi BUMN serta Penerapan Aspek Hukum Spin Off (Study Kasus PT Semen Padang). Tesis _ Pascasarjana Universitas Gadjah Mada Yogyakarta.

Muhadjir, N. (2002). Metodologi penelitian kualitatif. Yogyakarta: Rake Sarasin.

PP No. 59 Tahun 2009 tetang Perubahan atas Peraturan Pemerintah No.33 Tahun 2005. (n.d.).

PP No.33 Tahun 2005 tentang Tata cara Privatisasi Perusahaan Perseroan (Persero). (n.d.).

Samudro, Y. N. (2004). Laporan Keuangan Nilai Tambah sebagai Alternatif Laporan Keuangan Konvensional dalam Penilaian Kinerja Keuangan PT Indosat Sebelum dan Sesudah Privatisasi. Badan Pengkajian Ekonomi Keuangan Dan Kerjasama.

Shaoul, J. (1997a). A Critical Financial Analysis of the Performance of Privatised Industries/: The Case of the Water Industry in England and Wales. Critical Perspectives on Accounting, 8, 497-505.

Shaoul, J. (1997b). The Power of Accounting Reflecting on Water Industry Privatization. Accounting, Auditing, and Accountability Journal, 382-405.

Sokarina, A. (2011a). Analisis Kritis kinerja Pra dan Pasca Privatisasi dari Perspektif Political Economy of Accounting (Studi pada PT Telkom Tbk dan PT Indosat Tbk). Tesis-Prigram Magister Akuntansi Pascasarjana Fakultas Ekonomi Universtas Brawijaya Malang.

Sokarina, A. (2011b). Menggagas Dimensi Kinerja Perusahaan Berdasarkan Perspektif Political Economy Of Accounting (PEA). Simposium Nasional Akuntansi XIV Aceh 2011.

Tinker, A. M. (1980). Towards A Political Economy of Accounting/ : An Empirical Illustration of The Cambridge Controversies. Accounting, Organizations and Society., 5(1), 147-160.

UUD 1945. (1945). In Undang-undang Dasar Negara Republik Indonesia.

Widjajanti, K. (2013). Peningkatan Pengelolaan BUMN. In Peningkatan Pengelolaan BUMN (Vol. 53). doi:10.1017/CBO9781107415324.004 